\title{
PENGARUH LARI ZIG-ZAG BERBANTUAN KURSI TERHADAP PERKEMBANGAN MOTORIK KASAR ANAK KELOMPOK B TK SILA DHARMA
}

\author{
Sisilia Indah Trisnaningsih ${ }^{1}$, I Komang Ngurah Wiyasa², I Wayan Darsana ${ }^{3}$ \\ 1,2,3 Jurusan Pendidikan Dasar \\ Universitas Pendidikan Ganesha \\ Singaraja, Indonesia \\ e-mail: sisiliaindah02@gmail.com¹, ngrh.wiyasa@undiksha.ac.id², \\ iwayan.darsana@undiksha.ac.id²
}

\begin{abstract}
Abstrak
Penelitian ini bertujuan untuk mengetahui pengaruh lari zig-zag berbantuan kursi terhadap perkembangan motorik kasar anak kelompok B TK Sila Dharma Tahun Ajaran 2018/2019. Jenis penelitian ini Quasi Eksperimen (eksperimen semu) dengan menggunakan desain Nonequvalent Control Group Design. Populasi dari penelitian ini adalah seluruh kelompok B TK Sila Dharma yang berjumlah 96 anak. Sampel dalam penelitian menggunakan teknik random sampling, sehingga diperoleh kelompok eksperimen adalah kelompok B3 TK Sila Dharma yang berjumlah 23 anak dan kelompok kontrol adalah kelompok B2 TK Sila Dharma yang berjumlah 25 anak. Data perkembangan motorik kasar anak dikumpulkan dengan non test melalui observasi. Hasil dari penelitian ini menunjukkan rata-rata post-test perkembangan motorik kasar anak pada kelompok eksperimen adalah 85,87 sedangkan pada kelompok kontrol 78,80. Pengujian hipotesis yang digunakan dalam penelitian ini adalah uji t dengan menggunakan rumus polled varians pada taraf signifikansi $5 \%$ dengan $d k=23+25-2=46$ dengan nilai 2,021. Diperoleh $t_{\text {hitung }}=3,07>t_{\text {tabel }}=$ 2,021. Berdasarkan kriteria pengujian, maka $H_{0}$ ditolak. Dengan demikian dapat disimpulkan bahwa lari zig-zag berbantuan kursi berpengaruh terhadap perkembangan motorik kasar pada anak kelompok B TK Sila Dharma Tahun Pelajaran 2018/2019.
\end{abstract}

Kata-kata Kunci: Lari Zig-zag, Perkembangan Motorik Kasar, Anak Usia Dini

\begin{abstract}
This study aims to determine the effect of chair-assisted zigzag running on the gross motoric development of children in group B TK Sila Dharma Academic Year 2018/2019. This type of research is Quasi Experiment (quasi-experimental) using the Nonequvalent Control Group Design design. The population of this study were all Sila Dharma Kindergarten B groups of 96 children. The sample in the study used a random sampling technique, so that the experimental group was obtained from the B3 TK Sila Dharma group, which amounted to 23 children and the control group was the Sila Dharma B2 TK group of 25 children. Data on the gross motoric development of children were collected by non-test through observation. The results of this study showed that the average post-test for gross motoric development of children in the experimental group was 85.87 while in the control group 78.80. Testing the hypothesis used in this study is a t test using the polled variance formula at a significance level of $5 \%$ with $\mathrm{dk}=23+25-2=46$ with a value of 2.021. Obtained tcount $=3.07>\mathrm{t}$ table $=2.021$. Based on the testing criteria, $\mathrm{HO}$ is rejected. Thus it can be concluded that zig-zag running assisted by chair has an effect on gross motor development in group B of TK Sila Dharma Academic Year 2018/2019.
\end{abstract}

Keywords: Zigzag running, chairs, gross motor development, early childhood education 


\section{PENDAHULUAN}

Pendidikan Anak Usia Dini (PAUD) memegang peran yang sangat penting dalam perkembangan anak, hal ini karena anak sedari dini sampai memasuki pendidikan dasar merupakan masa keemasan (golden age) dalam rentang kehidupan manusia yang tidak bisa terulang. Pendidikan Anak Usia Dini (PAUD) ini bertujuan untuk membimbing dan mengembangkan potensi setiap anak agar dapat berkembang secara optimal sesuai dengan kemampuannya. Masa ini merupakan masa yang paling tepat untuk meletakkan aspekaspek pengembangan kemampuan diantaranya fisik, kognitif, bahasa, sosio-emosional, moral, dan seni. Dengan demikian, upaya pengembangan seluruh potensi anak harus dimulai pada usia dini supaya pertumbuhan dan perkembangan anak tercapai dengan maksimal.

Sesuai dengan keunikan dan perkembangan anak usia dini, penyelenggaraan pendidikan bagi anak usia dini harus disesuaikan dengan tahap-tahap perkembangan yang dilalui oleh anak. Menurut (Hurlock, 1978) dalam Mulyani (2016 : 18) dalam bukunya mengatakan perkembangan motorik adalah "perkembangan pengendalian gerakan jasmaniah melalui kegiatan pusat syaraf, urat syaraf, dan otot yang terkoordinasi". Perkembangan keterampilan motorik sangat penting bagi perkembangan self-concept atau kepribadian anak. Perkembangan fisik seperti, berjalan, berlari, melompat membutuhkan keterampilan motorik agar otot syaraf yang mulai tumbuh dapat berfungsi dengan baik. Dengan motorik yang bagus, seorang anak bisa dengan mudah dan lancar melakukan aktivitas lainnya untuk menunjang tumbuh kembangnya. Tugas perkembangan jasmani berupa koordinasi gerakan tubuh, seperti berlari, berjinjit, melompat, melempar dan menangkap. Pada masa ini, perkembangan motorik sudah dapat dilihat dan paling menonjol perkembangannya. Menurut (CRI, 1997) dalam Suryana (2016 : 155) tujuan pendidikan fisik untuk anak-anak adalah untuk mengembangkan keterampilan dan ketertarikan fisik dalam jangka panjang. Proses tumbuh kembang kemampuan motorik anak berhubungan dengan proses tumbuh kemampuan gerak anak. Perkembangan kemampuan motorik anak akan terlihat secara jelas melalui berbagai gerakan dan permainan yang dapat dilakukan. Apabila anak tidak mampu melakukan gerakan fisik dengan baik akan menumbuhkan rasa tidak percaya diri dan konsep diri negatif dalam melakukan gerakan fisik. Pertumbuhan perkembangan fisik anak usia dini tidak selalu sama. Ada beberapa anak yang mengalami pertumbuhan secara cepat dan ada pula yang mengalami keterlambatan.

Pada masa kanak-kanak ini, pertumbuhan tinggi badan dan berat badan relatif seimbang. Kebutuhan gizi yang cukup juga sangat penting untuk memenuhi kebutuhan dan pertumbuhan dalam masa perkembangan anak, termasuk dalam pekembangan gerak. Kekurangan gizi pada usia kanak-kanak akan mengakibatkan keterbelakangan dalam perkembangan gerak. Selain itu lingkungan juga dapat mempengaruhi perkembangan gerak anak usia dini. Sedari dini anak harus diberikan berbagai kegiatan fisik yang bervariasi yang memungkinkan mereka untuk bergerak. Jika seorang anak berhasil melakukan suatu aktivitas fisik atau gerakan, maka selanjutnya anak mau berpartisipasi kembali dalam kegiatan tersebut. Jadi dengan bertambahnya umur, seorang anak akan berkembang melalui suatu rangkaian tingkatan yang bertahap dan keterampilan baru akan disempurnakan.

Bergerak bagi anak usia dini merupakan salah satu bagian yang sangat penting di dalam kehidupannya. Jika anak terbiasa berolahraga atau bergerak sejak dini, maka anak akan mendapatkan pembentukan postur tubuh yang baik saat dewasa nanti. Selain itu, kegiatan berolahraga atau bergerak akan membuat tulang dan otot anak bertambah kuat. Macam-macam bentuk gerakan yang diperoleh anak merupakan langkah dalam memasuki tahap perkembangannya, yaitu perkembangan yang berhubungan dengan pengetahuan, nilai, sikap serta keterampilan gerak itu sendiri, kognitif, afektif, dan psikomotor. Hal penting yang perlu diketahui bahwa dalam usaha membina dan meningkatkan kesegaran jasmani salah satunya adalah dengan latihan kekuatan, daya tahan, dan beberapa unsur yang menyangkut dengan gerakan manusia, yakni: daya tahan otot, jantung, peredaran darah, 
dan pernapasan. Jika diterapkan pada anak usia dini maka perlu diciptakan latihan-latihan yang sesuai dengan tingkat usianya, kemampuan anak dan situasi serta kondisi masingmasing lembaga. Oleh sebab itu anak usia dini harus disiapkan ke arah kebutuhan gerak dasar olahraga melalui pendidikan jasmani yang disesuaikan dengan tahap perkembangan dan kematangannya.

Pada masa ini, tugas perkembangan jasmani anak ditekankan pada kelincahan, dan koordinasi gerakan tubuh. Menurut (Kinanti, 2016) kelincahan adalah kemampuan untuk mengubah arah atau posisi tubuh dengan cepat yang dilakukan bersama-sama dengan gerakan lainnya. Untuk melatih kelincahan, dibutuhkan bentuk latihan yang sesuai dan mengharuskan untuk dapat bergerak dengan cepat dan mengubah arah dengan lincah. Salah satunya adalah dengan kegiatan lari, adapun macam-macam bentuk latihan berlari yaitu: lari bolak-balik (shuttle run), lari zig-zag, dan lari jongkok berdiri (squat thrust). Selain mempunyai berbagai macam bentuk latihan lari, menurut (Pane, 2015) latihan lari mempunyai berbagai macam manfaat bagi kesehatan tubuh antara lain adalah: (1) dapat menurunkan berat badan; (2) meningkatkan stamina tubuh; (3) menjadikan jantung sehat; (4) mengurangi berbagai resiko penyakit.

Tampak pada saat observasi berlangsung terdapat beberapa anak terlihat masih kesulitan dalam melakukan gerakan secara cepat seperti berlari kemudian berbalik arah, pemanfaatan fasilitas yang sudah tersedia terlebih dulu dalam penerapan variasi lari belum terlaksana dengan baik, dan penggunaan waktu yang singkat dalam melakukan lari ini membuat anak kurang memperhatikan guru saat guru mencontohkan kegiatan lari. Oleh karena itu untuk mengembangkan kelincahan perlu adanya suatu kegiatan yang menarik dan menyenangkan bagi anak dengan keterlibatan guru secara optimal.

Melihat faktor penyebab masalah yang ada di TK Sila Dharma, maka perlu dirancang kegiatan alternatif yang dapat mengembangkan motorik kasar khususnya dalam melatih kelincahan dan kecepatan anak sekaligus mengatasi rasa jenuh saat melakukan kegiatan fisik motorik. Salah satu kegiatan alternatif yang dapat menyelesaikan permasalahan di TK Sila Dharma adalah dengan cara membuat kegiatan berlari zig-zag berbantuan kursi. Lari adalah cabang olahraga utama dalam atletik. Lari juga termasuk perlombaan yang paling digemari dalam atletik. Sebab, olahraga ini mudah dimainkan oleh siapa saja dan tidak membutuhkan aturan yang rumit serta tempat khusus. menurut Hadziq dan Anwar (2017 :

75) mengemukakan ada beberap bentuk latihan kelincahan antara lain sebagai berikut :

1. Berlari bolak-balik

Lari bolak-balik menuntut seseorang untuk dapat berlari dengan cepat, berhenti, dan berbalik arah, serta memulai lari kembali dengan cepat. Gerakan lari dipraktikan secara berulang-ulang.

2. Berlari berkelok melewati rintangan

Lari cepat berkelok melewati rintangan merupakan gerakan yang menuntut kelincahan. Kemampuan berhenti, mengubah arah dengan cepat tanpa kehilangan keseimbangan menunjukkan kelincahan seseorang dalam bergerak. Tempatkan beberapa rintangan dengan lintasan berkelok (zig-zag) kemudian praktikkan gerak latihan kelincahan dengan berlari cepat melewati rintangan.

3. Squat Trush

Squat trush merupakan bentuk latihan untuk meningkatkan kelincahan. Kemampuan untuk melakukan squat trush dari posisi berdiri-jongkok-lempar kaki kebelakang-jongkokberdiri (melompat ke atas) dengan cepat menunjukkan kelincahan seseorang dalam bergerak.

Lari zig-zag merupakan salah satu jenis olahraga yang mudah untuk diterapkan untuk anak usia dini. Menurut (Kerru dkk, 2015) lari zig-zag adalah jenis latihan yang dapat melatih keseimbangan dan ketangkasan ketika sedang bergerak (lari). Melakukan lari zig-zag berbantuan kursi ini mudah dilakukan untuk anak usia dini (PAUD) dan latihan ini hanya menggunakan benda atau fasilitas yang sudah ada, yaitu kursi. Meskipun lintasannya berliku-liku dengan kursi yang telah diatur, gerakan ini justru menjadi ciri khas tersendiri dan begitu unik. Karena anak berlari mengikuti rintangan dengan langkah kaki yang berirama. 
Sebelum berlari, anak diajak untuk melakukan pemanasan terdahulu guna pemanasan ini untuk mencegah cedera sehingga mengurangi nyeri otot, melancarkan pernapasan agar sirkulasi udara menjadi lebih stabil saat melakukan olahraga inti dan meningkatkan kelenturan tubuh. Dengan pemanasan, otot yang kaku dapat sedikit dilenturkan agar tidak menimbulkan rasa nyeri dan terhindar dari bahaya-bahaya yang lainnya.

\section{METODE}

Penelitian ini dilaksanakan pada anak kelompok B di TK Sila Dharma. Metode penelitian yang dilakukan dalam penelitian ini menggunakan metode quasi eksperimen (eksperimen semu). Penelitian eksperimen ini merupakan salah satu jenis penelitian kuantitatif dan menggunakan rancangan desain Nonequivalent Control Group Design.

Tabel 01

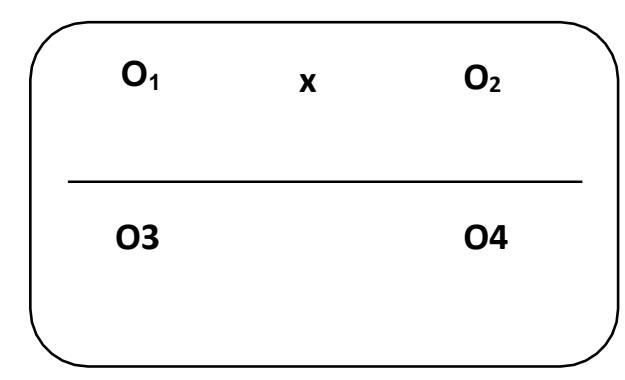

Rancangan “Nonequivalent Control Group Desain” (Sugiyono, 2014 : 116)

Keterangan :

$\mathrm{X}=$ Perlakuan berupa penerapan lari zig-zag berbantuan kursi terhadap kelincahan anak

$\mathrm{O}_{1}=$ Pre-test pada kelompok eksperimen

$\mathrm{O}_{2}=$ Post-test pada kelompok eksperimen

$\mathrm{O}_{3}=$ Pre-test pada kelompok kontrol

$\mathrm{O}_{4}=$ Post-test pada kelompok kontrol

Menurut Sugiyono (2014 : 297) populasi adalah "obyek/subyek yang mempunyai kualitas dan karakteristik tertentu yang ditetapkan oleh peneliti untuk dipelajari dan kemudian ditarik kesimpulannya". Populasi dalam penelitian ini adalah seluruh anak kelompok B yang terdiri dari 4 kelas. Jumlah populasi dari penelitian ini sebanyak 96 anak.

Menurut Siregar (2013: 30) sampel adalah suatu prosedur pengambilan data dimana hanya sebagaian populasi saja yang diambil dan dipergunakan untuk menentukan sifat serta ciri yang dikehendaki dari suatu populasi. Teknik pengambilan sampel ini menggunakan teknik Random Sampling yaitu mengacak kelas bukan siswa. Teknik yang digunakan ini melibatkan setiap kelas memiliki kesempatan yang sama. Pengambilan sampel dalam penelitian ini dilakukan dengan cara diundi.

Metode pengumpulan data yang digunakan adalah metode non test. Metode non test yang akan digunakan adalah metode observasi. "Observasi adalah pengamatan dan pencatatan yang sistematis terhadap gejala-gejala yang diteliti" (Usman, 2014: 53). Teknik analisis data yang digunakan untuk menganalisis data dalam penelitian ini adalah teknik statistik inferensial. Analisis statistik inferensial adalah suatu cara pengolahan data yang dilakukan dengan cara menerapkan rumus-rumus statistik inferensial untuk menguji suatu hipotesis penelitian yang diajukan peneliti, dan kesimpulan berdasarkan hasil pengujian 
terhadap hipotesis. Statistik inferensial digunakan untuk menguji hipotesis melalui uji-t yang diawali dengan analisis prasyarat yaitu uji normalitas dan uji homogenitas.

"Validitas internal menyangkut tingkat kualitas ketepatan pengendalian aspek fisikpsikologis pelaksanaan penelitian dan pemilihan atau penggunaan berbagai instrumen dalam pelaksanaan suatu penelitian"(Dantes, 2012 :88). Berikut sejumlah ancaman terhadap validitas internal dan cara-cara untuk mengontrol pengaruhnya dalam eksperimen.

1. Karakteristik Subjek

Pemilihan sampel penelitian baik secara kelompok maupun perorangan dapat menghasilkan kelompok yang tidak homogen atau tidak diinginkan, tetapi memiliki keterkaitan dengan variabel yang diteliti. Untuk menghindari hal ini dengan cara melakukan teknik random sampling. Teknik yang digunakan ini melibatkan setiap kelas memiliki kesempatan yang sama. Pengambilan sampel dalam penelitian ini dilakukan dengan cara diundi.

\section{Instrumentasi}

Ancaman instrumentasi bersumber dari perbedaan karakteristik pengumpulan data, seperti beda gender, umur, dan etnis (Dantes, 2012:90). Cara mengatasi ancaman ini adalah dengan cara melakukan uji validitas instrumen agar instrumen yang diukur benar-benar valid dan menggunakan pengamat atau observer yang berkualifikasi di bidang motorik kasar anak usia dini.

3. Kematangan (Maturity)

Perubahan yang terjadi pada subjek karena pengaruh waktu, bukan disebabkan oleh perlakuan yang diberikan dapat mempengaruhi hasil eksperimen. Untuk mengatasi hal tersebut, peneliti menggunakan dua kelas yaitu kelompok eksperimen dan kontrol dengan tingkatan kelas dan umur yang sama sehingga memiliki tingkat perkembangan yang sama.

Validitas eksternal instrumen diuji dengan cara membandingkan antara kriteria yang ada pada instrumen dengan fakta-fakta empiris yang terjadi di lapangan. Faktor yang bersifat eksternal dalam penelitian ini yang perlu dikontrol yaitu terletak pada sampel penelitian. Sampel menyadari bahwa diriya sedang dieksperimen menyebabkan generalisasi yang diperoleh tidak bisa berlaku bagi populasi karena adanya perbedaan pengalaman antar anggota sampel dengan populasi. Oleh karena itu perlu dilakukan kontrol terhadap prosedur eksperimen yaitu dengan cara mengajak anak agar merasa nyaman dan senang dalam mengikuti proses kegiatan selain itu gurulah yang mengajar anak di luar kelas, sehingga mereka tidak menyadari dirinya sedang dieksperimen.

Variabel terikat adalah variabel yang dipengaruhi atau menjadi akibat karena adanya variabel lain (variabel bebas) (Siregar, 2013). Variabel terikat dalam penelitian ini adalah perkembangan motorik kasar anak kelompok B. Bergerak bagi anak usia dini merupakan salah satu bagian yang sangat penting di dalam kehidupannya. Jika anak terbiasa berolahraga atau bergerak sejak dini, maka anak akan mendapatkan pembentukan postur tubuh yang baik saat dewasa nanti. Selain itu, kegiatan berolahraga atau bergerak akan membuat tulang dan otot anak bertambah kuat.

Keterampilan fisik yang dibutuhkan anak untuk kegiatan dan aktivitas olahraga bisa dipelajari dan dilatih dimasa-masa awal perkembangan. Pendidikan jasmani pada anak usia dini merupakan awal dari upaya pengarahan, pembinaan dan pengembangan potensi fisik serta karakter anak secara sistematik dan teratur dalam upaya mewujudkan cita-cita 
membangun manusia sehat dan kuat secara keseluruhan. Pada masa ini, tugas perkembangan jasmani anak ditekankan pada kelincahan, dan koordinasi gerakan tubuh, seperti berlari, melompat, bergantung, melempar dan menangkap. Dengan motorik yang bagus, seorang anak bisa dengan mudah dan lancar melakukan aktivitas lainnya untuk menunjang tumbuh kembangnya.

Perlakuan yang diperlukan dalam penelitian ini adalah lari zig-zag melewati kursi. Untuk meneliti di lapangan, peneliti menggunakan instrumen yang baik dan mampu mengambil informasi dari objek yang akan diteliti. Sehingga untuk memperoleh data yang baik diperlukan uji validitas pada suatu instrumen sebelum digunakan. Pada penelitian ini menggunakan uji validitas isi. Validitas isi menyangkut tentang isi dan format dari instrumen. Validitas isi berkenaan dengan ketepatan instrumen dalam suatu variabel yang akan diukur, serta ketepatan dan format instrumen.

Setelah dilakukan uji prasyarat, maka selanjutnya dilakukan uji hipotesis. Uji hipotesis pada penelitian ini menggunakan uji-t dengan kreteria penguji jika $t_{\text {hitung }}>t_{\text {tabel }}$ pada taraf signifikansi $5 \%$ dengan $\mathrm{dk}=\mathrm{n}_{1}+\mathrm{n}_{2}-2$ maka $\mathrm{H}_{0}$ yang menyatakan "tidak terdapat perbedaan yang signifikan perkembangan motorik kasar yang dibelajarkan menggunakan lari zig-zag berbantuan kursi dengan kelompok anak yang tidak dibelajarkan melalui lari zig-zag pada anak kelompok B TK Sila Dharma Tahun Ajaran 2018/2019" ditolak dan Ha yang menyatakan "terdapat perbedaan yang signifikan perkembangan motorik kasar anak melalui lari zig-zag berbantuan kursi dengan kelompok anak yang tidak dibelajarkan lari zig-zag pada anak kelompok B TK Sila Dharma Tahun Ajaran 2018/2019" diterima.

\section{HASIL DAN PEMBAHASAN}

Data yang dianalisis dalam penelitian adalah data skor motorik kasar anak kelompok B TK Sila Dharma Tahun Ajaran 2018/2019 pada kelompok eksperimen dan kelompok kontrol. Kelompok eksperimen dalam penelitian ini adalah kelompok B3 yang berjumlah 23 anak dan kelompok kontrolnya adalah kelompok B2 yang berjumlah 25 anak. Maka jumlah sampel dalam penelitian ini sebanyak 48 anak. Sebelum diberikan perlakuan pada kelompok eksperimen dan kelompok kontrol maka masing-masing kelompok diberikan pretest yang bertujuan untuk menyetarakan kelompok. Setelah kedua kelompok dinyatakan setara barulah diberikan perlakuan. Pada kelompok eksperimen diberikan perlakuan berupa lari zigzag sebanyak 6 kali pertemuan dan pada kelompok kontrol tidak diberikan perlakuan. Kemudian kedua kelompok diberikan postest untuk memperoleh skor motorik kasar. Deskripsi data nilai akhir untuk perkembangan motorik kasar anak yang memaparkan ratarata (mean), standar deviasi, varians, skor maksimum, dan skor minimum. Adapun rekapitulasi hasil deskripsi data dapat dilihat pada tabel berikut. 
Tabel 02. Deskripsi Data Kelompok Eksperimen dan Kontrol

\begin{tabular}{ccc}
\hline Hasil Analisis & Eksperimen & Kontrol \\
\hline Mean & 85,87 & 78,80 \\
Standar Deviasi & 75,94 & 51,50 \\
Varian & 8,71 & 7,18 \\
Skor Maksimum & 96 & 93 \\
Skor Minimum & 71 & 71 \\
\hline
\end{tabular}

Berdasarkan hasil analisis, menunjukkan bahwa perkembangan motorik kasar anak yang dibelajarkan melalui lari zig-zag berbantuan kursi memiliki nilai lebih tinggi dari kelompok anak yang tidak dibelajarkan motorik kasarnya melalui lari zig-zag berbantuan kursi. Selain itu pada kelompok eksperimen skor tertinggi yang dicapai anak adalah 96 dan skor terendah yang dicapai anak adalah 71. Sedangkan pada kelompok kontrol skor tertinggi yang dicapai anak adalah 93 dan skor terendah anak adalah 71. Sebelum dilakukan uji hipotesis, maka terlebih dahulu dilakukan uji prasyarat yaitu uji normalitas dan uji homogenitas. Uji normalitas sebaran data dilakukan untuk menyajikan bahwa sampel benarbenar berasal dari populasi yang berdistribusi normal dan menggunakan analisis ChiKuadrat. Kriteria pengujian data berdistribusi normal jika $X^{2}{ }_{\text {hitung }}<X_{\text {labe }}^{2}$ dengan taraf signifikansi $5 \%$.

Tabel 03. Uji Normalitas Data Post-test Kelompok Eksperimen dan Kontrol

\begin{tabular}{|c|c|c|c|}
\hline Sampel & $\mathbf{X}^{2}$ hitung & $\mathbf{X}_{\text {tabel }}^{2}$ & Kesimpulan \\
\hline Eksperimen & 2,85 & 11,07 & Berdistribusi Normal \\
\hline Kontrol & 6,24 & 11,07 & Berdistribusi Normal \\
\hline \multicolumn{4}{|c|}{$\begin{array}{l}\text { Uji normalitas data perkembangan motorik kasar anak kelompok eksperimen pada } \\
\text { pemberian post-test diperoleh } X^{2} \text { hitung }(2,85)<X_{l a b e}^{2}(11,07) \text { dan pada kelompok kontrol } \\
\text { diperoleh } X^{2} \text { hitung }(6,24)<X_{\text {tab }(11,07)}^{2} \text { sehingga dapat disimpulkan bahwa data berdistribusi } \\
\text { normal. Pengujian dilakukan dengan taraf sigifikansi } 5 \% \text { dengan dk pembilang } 23 \text { dan dk } \\
\text { penyebut } 25 \text {. }\end{array}$} \\
\hline
\end{tabular}

\section{PENUTUP}

Hasil perhitungan analisis data juga menunjukkan yaitu pada $\mathrm{dk}=46$ dan $\alpha=5 \%$ diperoleh ttabel $=3,07$ dan hasil pengujian hipotesis menunjukkan thitung $>$ ttabel yaitu 3,07 $>$ 2,02 sehingga $\mathrm{H}_{0}$ ditolak dan $\mathrm{H}_{\mathrm{a}}$ diterima. Perkembangan motorik pada anak usia dini lebih terlihat daripada perkembangan lainnya. Karena pada usia dini, anak mampu bergerak lebih lincah. Perkembangan motorik berbeda-beda pada setiap anak. Faktor yang mempengaruhi perkembangan motorik anak yaitu faktor makanan, faktor pemberian 
stimulus, dan factor lingkungan. Permasalahan yang terjadi pada penelitian ini adalah tentang perkembangan motorik kasar anak pada kelompok $B$ yang masih dalam kategori rendah sehingga proses dan tujuan dalam proses perkembangan motorik kasar belum tercapai secara optimal. Faktor yang mempengaruhi permasalahan motorik kasar ini diantaranya, saat diberikan senam anak tidak mau bergerak secara lincah dan cenderung bermain-main bersama temannya, kurang adanya fasilitas yang memadahi, dan kegiatan motorik kasar/fisik belum bervariasi. Penelitian ini bertujuan untuk mengetahui pengaruh lari zig-zag berbantuan kursi terhadap perkembangan motorik kasar anak kelompok B di TK Sila Dharma Tahun Ajaran 2018/2019. Selain mengetahui tujuan, penelitian ini memiliki manfaat yaitu manfaat teoretis dan manfaat praktis. Manfaat teoretis, dapat menambah wawasan serta masukan yang positif dan membangun pada bidang pendidikan anak usia dini, terlebih dalam pengembangan motorik kasar menggunakan lari zig-zag berbantuan kursi. Berdasarkan hasil penelitian dan pembahasan maka dapat disimpulkan bahwa perkembangan motorik kasar anak yang dibelajarkan melalui lari zig-zag berbantuan kursi pada anak kelompok eksperimen diperoleh rata-rata sebesar 85,87 dengan nilai tertinggi yang diperoleh 96 dan nilai terendah 71 sedangkan pada perkembangan motorik kasar yang tidak dibelajarkan melalui lari zig-zag pada anak kelompok kontrol diperoleh rata-rata sebesar 78,80 dengan nilai tertinggi 93 dan nilai terendah 71 . Rerata perkembangan motorik kasar terhadap anak yang dibelajarkan melalui lari zig-zag berbantuan kursi dengan perkembangan motorik kasar terhadap anak yang tidak dibelajarkan lari zig-zag berbantuan kursi $(85,87>78,80)$.

Berdasarkan hasil analisis dengan menggunakan uji-t diperoleh $t_{\text {hitung }}=3,07$ pada taraf signifikansi $5 \%$ dengan derajat kebebasan $(\mathrm{dk}=46)$ diperoleh $t_{\text {tabel }} 2,02$ sehinga $t_{\text {hitung }}=3,07$

$>t_{\text {tabel }} 2,02$. Dengan demikian, $H_{0}$ berbunyi "tidak terdapat perbedaan yang sgnifikan lari zigzag berbantuan kursi terhadap perkembangan motorik kasar anak kelompok B TK Sila Dharma Tahun Ajaran 2018/2019", ditolak dan $\mathrm{H}_{a}$ berbunyi "terdapat perbedaan yang signifikan lari zig-zag berbantuan kursi antara kelompok eksperimen dan kelompok kontrol terhadap perkembangan motorik kasar pada anak kelompok B TK Sila Dharma Tahun Pelajaran 2018/20119, diterima. Jadi dapat disimpulkan bahwa lari zig-zag berbantuan kursi berpengaruh terhadap perkembangan motorik kasar pada anak kelompok B TK Sila Dharma Tahun Pelajaran 2018/2019. Hasil penelitian ini dapat dijadikan sebagai bahan dalam pengkajian ilmu dibidang pendidikan khususnya dalam kegiatan fisik, dalam PAUD untuk memilih strategi pembelajaran yang bervariasi dalam mengajar. Salah satunya dengan menerapkan lari zig-zag dengan berbagai variasi dalam meningkatkan perkembangan motorik kasar anak. Saran yang dikemukakan dalam penelitian ini adalah guru yang mengajar di kelas B disarankan untuk membuat atau merancang kegiatan fisik yang dapat melatih kelincahan dan koordinasi tubuh. Selain itu, agar guru lebih kreatif untuk memberikan dan memanfaatkan fasilitas yang dibutuhkan dalam melatih kelincahan dan koordinasi tubuh bagi anak.

\section{UCAPAN TERIMAKASIH}

Pada kesempatan ini disampaikan ucapan terimakasih kepada :

1. Prof Dr. I Nyoman Jampel, M.Pd Rektor Universitas Pendidikan Ganesha atas kebijakan serta program-program yang dilaksanakan di Undiksha

2. Prof. Dr. Ni Ketut Suarni, M.S,Kons Dekan Fakultas IImu Pendidikan Ganesha atas kebijakan serta arahannya selama penyusunan skripsi ini. 
3. Drs. I Made Suarjana, M.Pd Ketua Jurusan Pendidikan Dasar yang telah memberikan legalitas dan memberikan pengarahan selama penyusunan skripsi ini.

4. Dr. Putu Aditya Antara, S.Pd,.M.Pd Koordinator Program Studi Pendidikan Guru Pendidikan Anak Usia Dini Fakultas Ilmu Pendidikan Ganesha

5. Drs. I Wayan Wiarta, S.Pd,.M.FOr Ketua UPP PGSD dan PGPAUD Undiksha Denpasar yang telah memberikan kesempatan menyusun skripsi ini.

6. Luh Ayu Tirtayani, S.Psi,.M.Psi,.Psikolog sekretaris PGPAUD Denpasar yang telah memberikan arahan dan bimbingan selama penyusunan skripsi ini.

7. Drs. I Komang Ngurah Wiyasa, M.Kes selaku Pembimbing I yang telah memberikan arahan, membimbing dengan ketelitian, motivasi, dan kesabaran selama penyusunan skripsi ini.

8. Drs. I Wayan Darsana, M.Ed selaku Pembimbing II yang telah memberikan arahan, membimbing dengan ketelitian, motivasi, dan kesabaran selama penyusunan skripsi ini.

9. Ni Made Warni,.S.Pd selaku Kepala Sekolah TK Sila Dharma yang telah memberikanizin untuk melaksanakan penelitian ini.

10. Komang Arik Anggraeni selaku guru kelompok B3 di TK Sila Dharma yang telah membantu dalam melaksanakan ini.

11. Bapak dan lbu Dosen serta staff pegawai di lingkungan jurusan PGSD dan PGPAUD, Undiksha kampus UPP II Denpasar yang banyak memberikan masukan, saran dan nasihat selama penyusunan skripsi ini.

\section{DAFTAR RUJUKAN}

Dantes. 2012. Metode Penelitian. Yogyakarta: Andi.

Hadziq, Khairul dan Anwar Musadad. 2017. Penjas Orkes Untuk Siswa SMA MA/SMK-MAK Kelas XI. Bandung: Yrama Widya.

Kinanti, Nurul Fajar. 2016. "PENGARUH LATIHAN ZIG ZAG RUN UNTUK MENINGKATKAN KELINCAHAN PADA PEMAIN SEPAK BOLA USIA 13-15 TAHUN DI SMP

MUHAMMADIYAH 5 SURAKARTA NASKAH." Universitas Muhammadiyah Surakarta. http://eprints.ums.ac.id/45295/26/NASKAH PUBLIKASIE.pdf.

Kerru, Alamsyah. Andi Saparia. Andi Sultan Brilin. 2015. "Pengaruh Latihan Shuttle Run Dan Lari Zig-Zag Terhadap Keterampilan Dribbling Dalam Permainan Bola Basket Pada Siswa SMP Negeri 1 Biromaru." Tadulako Physical Education, Health And Recreation 3 (12): 1-14. http://jurnal.untad.ac.id/jurnal/index.php/PJKR/article/download/5797/4557.

Mulyani, Novi. 2018. Perkembangan Dasar Anak Usia Dini. Yogyakarta: Gava Media.

Pane, Sitorus Bessy. 2015. "Peranan Olahraga Dalam Meningkatkan Kesehatan." Jurnal Pengabdian Kepada Masyarakat 21 (79): 1-4.

http://jurnal.unimed.ac.id/2012/index.php/jpkm/article/view/4646.

Siregar, Syofian. 2013. Metode Penelitian Kuantitatif. Jakarta: Prenadamedia Grup.

Sugiyono. 2014. Metode Penelitian Pendidikan Pendekatan Kuantitatif,Kualitatif, Dan R\&D. Bandung: Alfabeta.

Suryana, Dadan. 2015. Stimulasi Dan Aspek Perkembangan Anak. Jakarta: Kencana. 
Trisnaningsih, dkk., Vol. 7(1), 2019, 100-109

Usman, Husaini. 2014. Metodologi Penelitian Sosial. Jakarta: Bumi Aksara.

Wiyani, Novan Ardy. 2014. Psikologi Perkembangan Anak Usia Dini Panduan Bagi Orang Tua Dan Pendidik PAUD Dalam Memahami Serta Mendidik Anak Usia Dini. Yogyakarta: Gava Media. 